\title{
The Issue of the Rule of Law in Vietnam in the Constitution of 2013
}

\author{
Dinh Xuan $L y$
}

The Vietnamese Constitution of $2013^{1}$ is the basic law with the highest legal value of contemporary Vietnam. As a political-legal document it contains the following provisions: legal provisions on socio-political systems; state regime and the fundamental principles of organization and operation of the state apparatus; the legal status of the people, the fundamental rights and duties of citizens, economics and, culture as well as the relations between Vietnam and the international community.

The basis and objectives of Constitution formulation, implementation and protection of the Constitution of 2013 were recorded in the Preamble: "Institutionalizing the Platform for national construction during the transition to socialism and inheriting the Constitution of 1946, the Constitution of 1959, the Constitution of 1980 and 1992, the People of Vietnam have drafted, implemented and protected this Constitution for the sake of the well-being of the people, a strong country, democracy, equality and civilization." ${ }^{2}$ Therefore, to thoroughly understand the rule of law issues in Vietnam in the Constitution of 2013 , it is necessary to learn the viewpoints and policies of the Communist

${ }^{1}$ Constitution of the Socialist Republic of Vietnam (SRV) in 2013 (hereafter referred to as the Constitution of 2013) ratified by the National Assembly of the SRV of XIII, $6^{\text {th }}$ session on 28 November 2013; and President of the SRV signed the announcement order on 08 December 2013.

${ }^{2}$ National Political Publishing House (2014), 8. 
Party of Vietnam (CPV), since the Constitution of 1946 is directly related to the rule of law in Vietnam. ${ }^{3}$

\section{The Rule of Law's Provisions in the Constitution of 2013}

\section{Regarding the State Regime}

Clause 1, Article 2 of the Constitution of 2013, stipulates that "the State of the Socialist Republic of Vietnam is a state of the People, by the People and for the People."

This provision has clearly defined the nature of the rule of law in Vietnam to be a state of socialist rule of law, with government of the People, by the People, for the People.

Looking back at the history of Vietnam's Constitution since the August Revolution in 1945, the process of mobilization of state institutions in Vietnam was as follows: the Constitution of The Democratic Republic of Vietnam in 1946 stipulated that the country of Vietnam was a "democratic republic" (Article 1); the Constitution of the Democratic Republic of Vietnam in 1959 defined it as a "democratic state of the People" (Article 2); the Constitution of the SRV in 1980 stipulated, the "dictatorship of the proletariat" (Article 2); the Constitution of the SRV in 1992 stipulated the "State of the people, by the people, for the people" (Article 2); In 2001, Article 2 of the Constitu-

${ }^{3}$ From 1946 to the present (2014), Vietnam has promulgated five constitutions and named the Constitution of The Democratic Republic of Vietnam in 1946 (hereafter referred to as the Constitution of 1946); Constitution of the Democratic Republic of Vietnam in 1959 (hereafter referred to as the Constitution of 1959); Constitution of the Socialist Republic of Vietnam in 1980 (referred to as the 1980 Constitution); Constitution of the Socialist Republic of Vietnam in 1992 (referred to as the 1992 Constitution); and in 2001, the 1992 Constitution was amended and supplemented, but not renamed the Constitution (referred to as the amended Constitution in 2001); and Constitution of the Socialist Republic of Vietnam in 2013 (referred to as the Constitution of 2013)

${ }^{4}$ National Political Publishing House (2014), 8. 
tion of 1992, amended and supplemented by the provisions, "SRV is the socialist rule of law state of the people, by the people, for the people."

From the above study, it is shown that: In legal terms, the rule of law in Vietnam was stipulated in the Constitution of 1992 (already amended and supplemented by Resolution No. 51/2001/QH 10 dated 25 December 2001 of the National Assembly). And this provision is repeated in Clause 1, Article 2 of the Constitution of 2013.

When discussing the perception of rule of law of the CPV, some have opined that until the Convention of National Representatives in midterm VII (1994), the CPV "mainly considered the rule of law as a product of capitalism and acquired and inherited this perception." ${ }^{\circ}$ But the fact is that a month after the Seventh Convention of the National Congress Party, the issue of building the rule of law was officially mentioned by the General Secretary of the CPV, Do Muoi in his speech at the $9^{\text {th }}$ session of the National Assembly term VIII (dated 27 July1991) as follows:

"The National Congress should have focused on the implementation of two basic requirements: Firstly, building the rule of law, the state has the capacity to formulate a synchronous legal system to meet the new requirements of socio-economic development and manage all aspects of social civilization and progress; the legal system is the basis of ensuring the guidelines and policies of the Party and State that are implemented effectively, is a key factor in making the social relations become healthier and stronger. Secondly, to ensure the practical power and effectiveness of the National Congress that is defined by Constitutional provisions. "

More than two years later, at the midterm VII Convention of National Delegates (January 1994), CPV proposed the policy of "continuing to build and gradually perfect the rule of law in Vietnam. That is the state of the people, by the people, for the people, managing all aspects of social life by the law." Therefore, it can be said that the issue of building the rule of law in Vietnam

\footnotetext{
5 All quotations are taken from the paragraph: the Declaration of Independence in 1945 and the Constitution of Vietnam (1946, 1959, 1980, and 1992), National Political Publishing House (2006), 12, 31, 69, 125, 199.

${ }^{6}$ VNU. University of Social Sciences and Humanities. Faculty of Philosophy (2012), 536.

${ }^{7}$ Vietnam Communist Party (1994), 56.

${ }^{8}$ Vietnam Communist Party (2007), 340.
} 
has been formally laid out and directed by the CPV, as the ruling political party, since the second half of 1991.

The issue of building a socialist rule of law state in Vietnam continued to be thoroughly implemented through the National Congress Conventions of CPV and the Convention of the Party Central Committee. The policy of the Ninth National Congress Convention (April 2001) was to "build the socialist rule of law under the leadership of the Party". ${ }^{9}$ The Tenth National Congress Convention (April 2006) advocated "continuing to build and perfect the socialist rule of law state." ${ }^{10}$ By the Eleventh Party Congress Convention (January 2011), the Party urged to "continue to promote constructing and completing the socialist rule of law." 11 And, the program for national construction in the transition to socialism (Supplement, developed in 2011), defined: "our country is the state socialism of the People, by the People, for the People."12 Construction of state socialism of the people, by the people, for the people is one of the eight basic guidelines to build Vietnam to become a modern industrial country under socialist orientation. ${ }^{13}$ The view of the supplement program, developed in 2011 and the Eleventh Party Congress Convention has been thoroughly defined and institutionalized in the Constitution of 2013.

\section{Regarding the Subjectivity of State Power}

Clause 2, Article 2 of the Constitution of 2013, stipulates that:

"the SRV is owned by the people; all state power belongs to the people but the foundation is the alliance between the working class and the peasantry and the intelli gentsia."

Stipulating that "all state power belongs to the people" reflects the politicallegal status of people of Vietnam as the subject of state power in state socialist rule of law in Vietnam. The Constitution of 2013 stipulates that people perform state power by direct democracy, representative democracy through the

\footnotetext{
${ }^{9}$ Communist Party of Vietnam (2001), 131.

${ }^{10}$ Communist Party of Vietnam (2006), 126.

${ }^{11}$ Communist Party of Vietnam (2001), 246.

${ }^{12}$ Communist Party of Vietnam (2011), 85.

${ }^{13}$ Communist Party of Vietnam (2011), 72.

${ }^{14}$ National Political Publishing House (2014), 8.
} 
National Assembly, People's Councils and through other agencies of the state (Article 6). Among them, "the state guarantees and promote ownership rights of the people; recognizes, respects, protects and guarantees human rights, citizenship rights; implements the objectives of prosperous people, a strong country, democracy, justice, civilization, and all people have an abundant life, liberty, happiness and favorable conditions for a comprehensive development (Article 3)"; "The state agencies, officials and public servants have to respect the people, devotedly serve the people, in close contact with people, listen to their opinions and be subject to the supervision of the people; We struggle against corruption, wastefulness and all manifestations of bureaucracy, arrogance, authoritarianism" (Clause 2, Article 8); Vietnam Fatherland Front is considered as representative to protect the legitimate rights and interests, the legitimacy of the people (Article 9). The above provisions create the constitutional basis for the continuation of institutionalizing the relevant laws of the state power belonging to the people.

In fact, although under different interpretations, the Constitution of Vietnam since the August Revolution of 1945, specified "all state power belongs to the people", for instance; the Constitution of 1946 stipulates that "All authority in the country of Vietnam belongs to the people, regardless of race, sex, wealth, class, religion" (Article 1); "People have the right to approve the Constitution and the relations to the destiny of the country" (Article 21); Constitution of 1959, stipulates that "All power in the State of Vietnam Democratic Republic belongs to the people" (Article 4); Constitution of 1980, stipulates that "All power belongs to the people" (Article 6); The Constitution of 1992 stipulates "the State of the Socialist Republic of Vietnam is a State of the people, by the people and for the people. All State power belongs to the people that the foundation is working class allied with the peasantry and intellectual classes" (Article 2). ${ }^{15}$ However, to the Constitution in 2013, has specified new mechanisms for people to exercise their state power.

In the reform era (since 1986), the viewpoint of the CPV on the subjectivity of state power belonging to the people and associated with the policy of building a law-governed state socialism in Vietnam has been proposed since

${ }^{15}$ All quotations are taken from the paragraph: the Declaration of Independence in 1945 and the Constitution of Vietnam (1946, 1959, 1980, and 1992). National Political Publishing House (2006), 12, 31, 70, 125. 
the beginning of the 1990s, with the requirement "to secure power and effectiveness in the practice of Congress, regulated by Constitutional provisions". The actual power of the Parliament is the indirect power of people through national members of parliament who are elected. The Ninth Party Congress affirmed "our country is the main tool for the implementation of the people's sovereignty, the rule of law of the people, by the people, for the people"; ${ }^{16}$ the Tenth Party Congress (April /2006), which set out requirements "to develop operational mechanisms of socialist rule of law, ensuring the principles of all state power belonging to the people"; ${ }^{17}$ the Eleventh Party Congress (1/2011) emphasized the policy of building and perfecting state socialist rule of law, ensuring our State is of the people, by the people and for the people. ${ }^{18}$ Supplementary Program developed in 2011, determined "all State power belongs to the people that its foundation is the alliance between the working class and the peasantry and the intelligentsia led by the CPV." 19 The view of the CPV on the subjectivity of state power in legitimate state socialism in Vietnam has been institutionalized by the 2013 Constitution.

\section{The Issue of Decentralization among State Authorities}

Clause 3, Article 2 of the Constitution of 2013 stipulates

"State power is unified with the assignment, coordination and control among state agencies in the implementing of the legislative, executive and justice rights. ${ }^{20}$

Earlier, the Constitution of the SRV in 1992 (Amended and supplemented in 2001), has stipulated "state power is unified with the assignment and coordination among state agencies in the implementing of the legislative, executive and judiciary rights" (Article 2). ${ }^{21}$ In Clause 3, Article 2, of the Constitution of 2013, the word "control" has been added which means "controlling the power". The stipulation of the principle of "controlling the power" in the Consti-

\footnotetext{
${ }^{16}$ Communist Party of Vietnam (2001), 131.

${ }^{17}$ Communist Party of Vietnam (2006), 126.

${ }^{18}$ Communist Party of Vietnam (2011), 246.

${ }^{19}$ Communist Party of Vietnam (2011), 85.

${ }^{20}$ National Political Publishing House (2014), 9.

${ }^{21}$ Declaration of Independence of 1945 and the Constitution of Vietnam (1946, 1959, 1980, 1992), National Political Publishing House (2006), 199.
} 
tution is progress in the constitutional history of Vietnam, this is the first time "controlling the power" has become a constitutional principle of the rule of law, the mechanism for the legislature, executive, and judiciary to enforce the effective, efficient functions, duties and powers under the Constitution and laws, avoiding misuse and abusing of power. The Constitution of 2013, specifies the competence of the power branches, the rule of law in socialism in Vietnam, such as the National Assembly exercises the constitutional functions, and decides important issues of the country, and exercises supreme control over the activities of the state (Article 69); the government is the supreme state administration agency of the SRV performing executive power, the executive agency of the National Assembly (Article 94); People's Court is the judicial agency of the SRV implementing judicial right (Article 102). Thus, the Constitution of 2013 had the clear assignment (decentralization) between the power branches of the state socialist rule of law in Vietnam:

"It is an important basis for relevant agencies to work together more rhythmically. Also, a power control mechanism has been identified, in which people's rights as owner of all state power is enhanced; the forms of democracy are expanding. The oversight role and social criticism of the Vietnam Fatherland Front and its member organizations are confirmed. "22

The fact is that the views of the CPV on assignment (decentralization) between the power branches of the socialist rule of law are recorded in the Party Program of 1991. The Vietnamese State unified three rights: legislative, executive and judicial rights with clear assignment of these rights; the viewpoint of the Eighth Party Congress was: state power is unified with the assignment and coordination among government agencies in the implementation of legislative, executive and judiciary rights. ${ }^{23}$ This is also the viewpoint of decentralization of the Ninth Party Congress. The Tenth Party Congress (April 2006) also continued to advocate the policy of "state power is unified with the assignment and coordination among agencies in exercising the legislative, executive and judiciary right." The Eleventh Party Congress stipulates that the "principle of state power is unified, with the assignment, coordination and control among agencies in the implementation of legislative, executive and judiciary rights." ${ }^{24}$

\footnotetext{
${ }^{22}$ Hoang The Lien (2014).

${ }^{23}$ Communist Party of Vietnam (1996), 45.

${ }^{24}$ Communist Party of Vietnam (2011), 247.
} 
The Supplementary Program developed in 2011, determined that: "state power is unified; with the assignment, coordination and control among relevant agencies in the implementation of the legislative, executive and judiciary rights." 25 The viewpoint of the Party on decentralization among the power branches in the rule of law in Vietnam in the Supplementary Program, developed in 2011, has been institutionalized in the Constitution of 2013.

\section{Regarding the Position of the Law toward Vietnamese State and Society}

Clause 1, Article 8 of the Constitution of 2013, stipulates that: "the State is organized and operated under the Constitution and law, social management defined by the Constitution and laws, implemented the principle of democratic centralization"; Clause 3, Article 9, stipulates "Vietnam Fatherland Front and its member organizations and other civil societies operate in the framework of the Constitution and law". In relations with the world community, Article 12 stipulates that the SRV comply with the United Nations Charter and international treaties in which the SRV is a member; contribute to the cause of peace, national independence, democracy and social progress in the world. ${ }^{26}$ Earlier, the Constitution of the SRV in 1980 had stipulated: State

${ }^{25}$ Communist Party of Vietnam (2011), 85.

${ }^{26}$ The Constitution of 1946 does not contain provisions on relations of Vietnam with the international community; Constitution of 1959 did not also set out specific rules, but the Preamble has written that: strengthening solidarity with the socialist faction and the peace-loving people in the world; the Constitution of 1980 stipulates that: Strengthen friendship and cooperation in all aspects with the socialist countries on the basis of Marxism-Leninism and proletarian internationalism; friendly relations with neighboring countries, with peoples struggling for national independence and social progress; policy implementation peaceful coexistence between countries with different socio-political systems; actively support and contribute to the struggle against imperialism, colonialism, hegemony, neo-racism, for peace, national independence, democracy and socialism (Article 14); the Constitution of 1992, which regulates the relations of Vietnam with the international community, essentially the same as the 1980 Constitution, but in which there are noteworthy changes, such as: 1) emphasizing the implementation of a policy of peace, friendship, expand exchanges and cooperation with all countries in the world, irrespective of the political regime and different societies; 2) not directly mentioning imperialism, colonialism, hegemony etc.; 3) not declaring socialism as a common and global target. In 2001, the Constitution kept the above mentioned content. 
management in accordance with law and unceasingly strengthening socialist legality. All State agencies, social organizations, government employees, staff of social organizations and all citizens must strictly abide by the Constitution and laws, to resolutely prevent and fight against the crime, violation of the constitution and the law (Article 12). The basic contents above were inherited in the 1992 Constitution.

In comparison with the 1980 Constitution and the 1992 Constitution, it shows that the provisions of the Constitution in 2013 strongly reflected the high appreciation of the legal system, and legislation became the basic characteristic of the rule of law in Vietnam. This can be considered a development of political thought.

\section{State Legislative Jurisdiction in the Constitution of 2013}

Since 2013, the Communist Party Congress of Vietnam term VI (December 1986), has set out the policy: "heightening the position and role of National Assembly and people's Councils at all levels, enabling the elected bodies to comply with the functions, duties and powers under the Constitution's stipulation. Strengthen the socialist legal and social management by law;" ${ }^{27}$ the Seventh Party Congress (June 1991) states guiding viewpoints: "the important condition for promoting democracy is to build and complete a system of laws and strengthen socialist legislation, improve the intellectual level, the level of legal understanding and awareness of law-abiding of the people;" 28 the $8^{\text {th }}$ Party Congress (June 1996) advocated "strengthening socialist legislation, building the rule of law in Vietnam, society managed by law, and emphasis on education, improve morality;" 29 the $9^{\text {th }}$ Party Congress: "State managing the society by law. All agencies, organizations, officials, public servants and all citizens are obliged to abide by the constitution and the law;" 30 the $10^{\text {th }}$ Party Congress (April 2006), proposed the policy of "perfecting the legal system, increasing specificity, feasibility of the provisions in the legislation documents. Preparing, compiling the checking mechanism, monitoring the constitutional-

\footnotetext{
${ }^{27}$ Communist Party of Vietnam (1987), 226.

${ }^{28}$ Communist Party of Vietnam (1987), 90-91.

${ }^{29}$ Communist Party of Vietnam (1996), 129.

${ }^{30}$ Communist Party of Vietnam (2001), 132.
} 
ity and legality of the activities and decisions of public authorities;"31 the Eleventh Party Congress (February 2011), which proposed the requirements on "improving the capacity management and administration of the State under the law, to strengthen socialist legality and discipline;"32 the supplementary program, developed in 2011, determines: "the State shall enact laws; organize and manage the society by law and constantly strengthen the socialist legality." ${ }^{33}$ Thus, in the period of innovation, strengthening of the legal issues and the management of the State under the constitution and laws, were deeply concerned by CPV with the policies strongly reaffirmed their determination to implement the "organization and management of society by law."

\section{On the Issue of Human and Civil Rights}

Clause 1, Article 14 stipulates that: In the RSV, human rights, the political, civil, economic, cultural, social rights of citizens have been recognized, respected, protected and guaranteed by the Constitution and laws; everyone is equal before the law. No one is discriminated in political, civil, economic, cultural and social life (Clause 1, Clause 2, and Article 16).

In addition, the 2013 Constitution also specified the human rights and civil rights in specific areas, such as the right to life, human life is protected by law (Article 19); everyone has the right to inviolability of the body and protected by law on the health, honor and dignity (Article 20); the right to inviolability of private life (Article 21); citizens have the right to have a legal residence (Article 22); everyone has the right to freedom of belief and religion, to follow or not follow a religion (Article 24; citizens have freedom of speech, freedom of the press, access right to information, assembly, association and demonstration (Article 25); men and women are equal in all aspects (Article 26); citizens have the right to participate in managing state and society (Article 28); ); everyone has ownership right of lawful income (Article 32); right to guarantee social security (Article 34); citizens have the right to work, to choose care, employment and workplace (Article 35); the right to marry and divorce (Article 36); rights to enjoy and access to cultural values, rights to participate

\footnotetext{
${ }^{31}$ Communist Party of Vietnam (2006), 126-127.

${ }^{32}$ Communist Party of Vietnam (2011), 247.

${ }^{33}$ Communist Party of Vietnam (2011), 85.
} 
in cultural life, to use cultural facilities (Article 41), right to determine the ethnicity (Article 42), the right to live in healthy environment (Article 43).

Overall, the Constitution of 2013 has amended and supplemented provisions on human rights, fundamental rights and duties of citizens; confirmed and clarified the principles of human rights; clarified the content of human rights, fundamental rights and duties of citizens in political, civil, economic, social, cultural affairs and the responsibility of the state and society in respecting, guaranteeing and protecting human rights; presented more clearly as the responsibility of the State in ensuring the implementation of human rights and civil rights. The provisions of human rights is consistent with international treaties to which Vietnam is a member, expressed the clearer awareness of human rights and affirmed a strong commitment of Vietnam in implementing human rights.

\section{Some Emerging Issues}

\section{The Concept of the Rule of Law and the Socialist Rule of Law}

It is a fact that there are many different interpretations of the rule of law. The report titled "Organizational structure and operation of socialist rule law state of the People, by the People, for the People in Vietnam in the period of industrialization and modernization", code KX04-02, provides comments: "The concept of "the rule of law" is used very differently. We can say for sure that documents such as the US Constitution, the French Declaration on human and civil rights, the American Declaration of Human Rights do not use the concept of the rule of law. The Germans have the concept "Rechtsstaat" and the French use the term "État de Droit", the Russians "Pravavoe gosudarstvo". All these three concepts of the Europeans can be generalized as "The government must be bound by law." 34

Meanwhile, researchers in Vietnam launched various conceptions of the rule of law according to the following three trends. The first tendency, the rule of law concept is a model of a state. This trend considered the rule of law state as "a type of state that is built on the basis of democratic opposition to the authoritarian state (...) The rule of law state does not just mean that the state is ruled by law. Many

${ }^{34}$ Nguyen Dang Dung (2007), 34-35. 
totalitarian states in history were ruled by law (...) If the principle of dictatorship and of a tyranny state is that the people have to obey the state then the principle of the rule of law is a state that is obedient to the citizens. The first condition of the rule of law is to guarantee the rights and freedoms of citizens by the clear provisions of the law. In the rule of law state, the law is the measure (norm) of freedom (...) This includes two sides closely related to each other: the law guarantees the rights and freedoms of citizens - every state organ and citizen has to obey the law. The rule of law, therefore, is built on the principles of democracy. The bodies of state power (legislative, executive and judicial) are elected freely with direct participation of all citizens to be able to adequately represent their will. Historical experience shows how these powers should be organized so that each power has real independence. All those appointed to bodies of state power must bear full responsibility before the citizens. The rule of law is the state model most likely to combat a monopolistic and bureaucratic power apparatus. 135

The second trend is based on the perception of the rule of law state as a method to organize and operate the society on the basis of these rights.

"These rights are assigned and organized so that abuses cannot occur and the democratic freedoms of the people are protected. The Constitution is the most important tool to define and delimit the rights. The Constitution is regarded as the soul of the rule of law. ${ }^{336}$

The third trend, the perception of the rule of law not as a state model but as common values, and the expression of a democratic development level. This trend sees the rule of law state as an organization of democracy; a state and social organizations based on democracy. The rule of law as a method of organizing and implementing a state regime and society is built not only in capitalism, but also in a socialist regime. ${ }^{37}$

${ }^{35}$ Nguyen Khac Vien (1994), 207-208.

${ }^{36}$ Nguyen Dang Dung (2007), 28.

${ }^{37}$ This opinion expresses that: The common values of the rule of law are presented in different forms and depend on the political-legal standpoint, academic viewpoint of each person, but in reality, emphasize the following values: 1) the rule of law is the fundamental pattern of democracy. Accordingly, democracy is both the essence and prerequisite for building the rule of law; 2) a legitimate state apparatus is organized and operated on the basis of the principles of organization of power in a democratic manner; 3) a judicial regime is truly democratic; judicial authorities only comply with the law with a public procedural regime and democracy. See also Nguyen Duy Quy (2007). 
Thus, in fact there are two different perspectives on the rule of law among Vietnamese researchers:

- Firstly, the viewpoint that the rule of law is a state model (a state); with this perspective, it is understandable that there is only one state model the rule of law in the world.

- Secondly, the perspective that the rule of law is the common value, the expression of a democratic development level; with this view, it is claimed that there is a bourgeois rule of law and a socialist rule of law.

\section{Some Issues of a Socialist Rule of Law State in Vietnam}

Constitutional amendments in 2001 and then the Constitution of 2013 stipulate that the State of Vietnam is a socialist rule of law state of the people, by the people and for the people. This provision marks the process of the CPV's innovative thinking about state politics. This is regarded as a theoretical achievement of innovation marking the transition in the perception of the ruling party "the rule of law is not something separated from capitalism. Socialism must practice the rule of law. ${ }^{38}$

Through researching some concepts, perspectives and the reality of the rule of law, at a certain level the fundamental characteristics of the rule of law can be proposed as such: 1) the law holds supremacy in the state and society; 2) the people are the source of state power; 3) human rights, citizenship rights are confirmed and guaranteed; 4) there is a clear separation of powers among the legislative, executive and judicial; 5) the rule of law has capable most of countering the monopolistic trend of power and bureaucratic tendency of a power apparatus. ${ }^{39}$

By the Constitution of 2013, the socialist rule of law state model in Vietnam can be visualized based on the following fundamental features:

- On the nature of the rule of law in Vietnam - a legitimate state socialism; the government of the People, by the People, for the People.

${ }^{38}$ Communist Party of Vietnam (2005), 143.

${ }^{39}$ It was also suggested that the rule of law has some typical features such as: 1) the supremacy of the constitution; 2) the objective of ensuring the freedom and equality of human beings, as opposed to state violence or an authoritarian state; 3) a state against the abuse of power and organized on the principle of decentralization. See also: Nguyen Dang Dung (2007), 63-67. 
- Regarding the fundamental characteristic of the socialist rule of law - all State power belongs to the people; the foundation is the alliance between working class, the peasantry and intelligentsia.

- Regarding the operational mechanisms of the bodies of state power - state power is unified with the assignment, coordination and control among state agencies in the implementation of the legislative, executive and judiciary rights.

- Regarding the position of law in the state and society - the State of Vietnam is organized and operating under the Constitution and law, social management by the Constitution and laws implement the principle of democratic concentration; theVietnam Fatherland Front and its member organizations and other civil society organizations operate in the framework of the Constitution and the law.

- Human rights, and the rights of citizens in political, civil, economic, cultural, social affairs are recognized, respected, protected and guaranteed by the Constitution and law; all persons are equal before the law.

In comparison with the fundamental characteristics of the rule of law in general, the socialist rule of law state in Vietnam has the following characteristics.

In the Preamble, an important foundation for the construction of the Constitution of 2013, is the "Institutionalization of the Programme for national construction in transition to socialism" and Article 4 of the Constitution in 2013, stipulates that the CPV is the leading force of the State and society. Since then it is shown that the socialist rule of law in Vietnam is essentially characterized as the organization and operation under the leadership of the CPV. Therefore, the question is to scientifically determine the relationship between the leadership of the CPV and the socialist rule of law as to how to ensure the effective and efficient operation of the State of the socialist rule of law in Vietnam.

One of the fundamental features of the rule of law is the clear separation of powers between the legislative, executive and judicial. The Constitution of 2013, the provisions in the socialist rule of law state in Vietnam is that the National Assembly shall exercise the constitutional, legislative power (Article 69); the Government implement executive powers (Article 94); People's courts implement judicial power (Article 102). The delimitation of such powers is quite clear, however, and Article 100 stipulates "The government, the Prime Minister, ministers, heads of ministerial-level agencies enact laws to imple- 
ment tasks and their powers, supervise the implementation of those documents and handle unlawful documents as prescribed by law." ${ }^{40}$ Thus it is understandable that apart from Parliament, the "Government, Prime Minister, ministers; heads of ministerial-level agencies" are also empowered by people to "enact law documents". Before, the Constitution of 1992 stipulated that "the National Assembly is the only body with constitutional and legislative rights (Article 83)." ${ }^{41}$

\section{Summary}

In summary, and under a legal perspective, the socialist rule of law of Vietnam officially was initially enacted in the Constitution of the SRV in 1992 (already amended and supplemented by Resolution No. 51/2001/QH 10 dated 25 December 2001 of the National Assembly). In the Constitution of 2013, new provisions have been added "on the organization and operation of the state apparatus in accordance with the rule of law and the excellent organizing principle of state power in Article 2 of the Constitution." ${ }^{2}$

\section{References}

Communist Party of Vietnam (ed.) (1987): Documents of the Sixth National Congress. Hanoi.

Communist Party of Vietnam (ed.) (1996): Documents of the Eighth National Congress. Hanoi.

Communist Party of Vietnam (ed.) (2001): Documents of the Ninth National Congress. Hanoi.

Communist Party of Vietnam (ed.) (2005): Report on Some TheoreticalReality Issues over 20 Years of Reform (1986-2006). Hanoi.

\footnotetext{
${ }^{40}$ National Political Publishing House (2014), 54.

${ }^{41}$ Declaration of Independence of 1945 and the Constitution of Vietnam (1946, 1959, 1980, 1992). National Political Publishing House (2006), 150.

${ }^{42}$ Hoang The Lien (2014).
} 
Communist Party of Vietnam (ed.) (2006): Documents of the Tenth National Congress. Hanoi.

Communist Party of Vietnam (ed.) (2011): Documents of the Eleventh National Congress. Hanoi.

Hoang The Lien (2014): The New Points of the Constitution (amended) of the Government http://www.nhandan.com.vn/chinhtri/tuyentruyenhienphap/item/22697502-nhung-diem-moi-cua-hien-phap-sua-doi-ve-chinh-phu.html.

National Political Publishing House (ed.) (2006): Declaration of Independence of 1945 and the Constitution of Vietnam (1946, 1959, 1980, 1992). Hanoi.

National Political Publishing House (ed.) (2014): Constitution of the Socialist Republic of Vietnam. Hanoi.

Nguyen Dang Dung (ed.) (2007): National Assembly of Vietnam in the Rule of Law. Hanoi.

Nguyen Duy Quy (2007): Construction and Finishing Legitimate Socialist State of Vietnam. In: Journal of Philosophy 11 (198).

Nguyen Khac Vien (ed.) (1994): Dictionary of Sociology. Hanoi.

Vietnam Communist Party (ed.) (1994): Document of National Representatives Convention. Midterm VII, Internal Circulation, May 1/1994.

Vietnam Communist Party (ed.) (2007): Party Documentation Vol. 51. Hanoi.

VNU. University of Social Sciences and Humanities. Faculty of Philosophy (ed.) (2012): The Rule of Law: some Theoretical and Practical Issues. Proceedings of the International Scientific Conference. Hanoi. 